\title{
The Impact of Heterogeneous NOx Regulations on Distributed Electricity Generation in U.S. Manufacturing
}

by

\author{
Jonathan M. Lee \\ East Carolina University
}

CES 15-12 April, 2015

The research program of the Center for Economic Studies (CES) produces a wide range of economic analyses to improve the statistical programs of the U.S. Census Bureau. Many of these analyses take the form of CES research papers. The papers have not undergone the review accorded Census Bureau publications and no endorsement should be inferred. Any opinions and conclusions expressed herein are those of the author(s) and do not necessarily represent the views of the U.S. Census Bureau. All results have been reviewed to ensure that no confidential information is disclosed. Republication in whole or part must be cleared with the authors.

To obtain information about the series, see www.census.gov/ces or contact Fariha Kamal, Editor, Discussion Papers, U.S. Census Bureau, Center for Economic Studies 2K132B, 4600 Silver Hill Road, Washington, DC 20233, CES.Papers.List@census.gov. 


\begin{abstract}
The US EPA's command-and-control NOx policies of the early 1990s are associated with a 3.1 percentage point reduction in the likelihood of manufacturing plants vertically integrating the electricity generation process. During the same period California adopted a cap-and-trade program for NOx emissions that resulted in no significant impact on distributed electricity generation in manufacturing. These results suggest that traditional command-and-control approaches to air pollution may exacerbate other market failures such as the energy efficiency gap, because distributed generation is generally recognized as a more energy efficient means of producing electricity
\end{abstract}

\footnotetext{
* Lee: East Carolina University, Brewster A426, 10th Street, Greenville, NC 27858 (e-mail: leejo@ecu.edu). The research reported herein was conducted while the author was a Special Sworn Status researcher of the U.S. Census Bureau at the Triangle Census Research Data Center. Any opinions and conclusions expressed herein are those of the author and do notnecessarily represent the views of the U.S. Census Bureau. All results have been reviewed to ensure that no confidential information is disclosed. The author thanks Pete Maniloff and seminar participants at the Southern Economic Association Annual Meeting for their helpful comments.
} 


\title{
The Impact of Heterogeneous NOx Regulations on Distributed Electricity Generation in U.S. Manufacturing
}

\author{
By JONATHAN M. LEE* (DRAFT 1: 3/20/2015)
}

The US EPA's command-and-control NOx policies of the early 1990s are associated with a 3.1 percentage point reduction in the likelihood of manufacturing plants vertically integrating the electricity generation process. During the same period California adopted a cap-and-trade program for NOx emissions that resulted in no significant impact on distributed electricity generation in manufacturing. These results suggest that traditional commandand-control approaches to air pollution may exacerbate other market failures such as the energy efficiency gap, because distributed generation is generally recognized as a more energy efficient means of producing electricity.

\footnotetext{
*Lee: East Carolina University, Brewster A426, 10 ${ }^{\text {th }}$ Street, Greenville, NC 27858 (e-mail: leejo@ecu.edu). The research reported herein was conducted while the author was a Special Sworn Status researcher of the U.S. Census Bureau at the Triangle Census Research Data Center. Any opinions and conclusions expressed herein are those of the author and do not necessarily represent the views of the U.S. Census Bureau. All results have been reviewed to ensure that no confidential information is disclosed. The author thanks Pete Maniloff and seminar participants at the Southern Economic Association Annual Meeting for their helpful comments.
}

Economists have long agreed that price-based instruments such as capand-trade and emission taxes are preferable to command-and-control approaches such as emission standards and clean technology mandates for reducing damages from pollution externalities (see, for example, Coase, 1960, Dales, 1968, Pigou, 1920). The key preferable features unique to these market based regulatory 
instruments are the promotion of lowest cost abatement within firms and across firms by equalizing marginal abatement costs of different polluting sources, and government revenues can be used to reduce distortionary taxes on other goods (Goulder and Parry, 2008).

This study provides additional evidence regarding the performance of market based environmental policy instruments over traditional command-andcontrol regulatory approaches in regards to the latter's failure to equate marginal abatement costs across sources. Specifically, it provides evidence that commandand-control approaches induce manufacturing plants to vertically disintegrate distributed electricity generating processes. Empirical results suggest that manufacturing plants participating in the US EPA's command-and-control NOx Reasonably Available Control Technology (RACT) program are 3.1 percentage points (significant at the $1 \%$ level) less likely to vertically integrate the electricity generating process in comparison to their non-participating counterparts. These tendencies toward vertical disintegration are lessened under a cap-and-trade regime, and empirical results do not find any statistically significant impact of California's Regional Clean Air Incentives Market (RECLAIM) on the degree of electricity vertical integration in manufacturing.

These results also suggest that cap-and-trade is a preferred policy instrument from an energy efficiency standpoint because distributed generation in any form avoids the 6-8\% electricity transmission losses from traditional market procurement (Shipley et al., 2008). Additionally, combined heat and power distributed generation systems have up to an $80 \%$ operating efficiency in comparison to the $45 \%$ combined efficiency of traditional boiler steam and power plant electricity systems. Finally, cap-and-trade instruments provide incentives for energy efficiency investments in upstream production processes that are not incentivized by process-specific emission standards (e.g. boiler, internal combustion engine, kiln and incinerator standards) and technology mandates. The 
empirical results presented in this paper suggest that RECLAIM participation is associated with a $22 \%$ increase in average energy productivity at manufacturing plants, and NOx RACT participation is associated with a $4 \%$ reduction in average productivity.

Aside from the pollution externalities associated with electricity generation, several recent studies suggest there may be an additional market failure relating to investment decisions in energy efficiency (e.g. Allcott and Greenstone, 2012, Bennear and Stavins, 2007, Fischer and Newell, 2008, Goulder and Parry, 2008). An energy efficiency gap between realized and optimal investment levels may result from imperfect information among firms, behavioral anomalies such as inattention or heavily discounting future energy savings, and network externalities in the form of knowledge spillovers from energy efficient R\&D investments (Allcott and Greenstone, 2012, Fischer and Newell, 2008). In the presence of multiple market failures, addressing only one of the failures does not necessarily lead to a Pareto improvement (Lipsey and Lancaster, 1956). Bennear and Stavins (2007) further clarify the problem as it is relevant for pollution and energy efficiency investment failures by noting that "market failures can be jointly ameliorating (correction of one market failure ameliorates welfare losses from the other), jointly reinforcing (correction of one market failure exacerbates welfare losses from the other), or neutral (correction of one market failure does not affect the welfare losses from the other)."

In this light cap-and-trade instruments are ameliorating to the inefficiencies from investment failures if they incentivize plant's investments in energy efficiency and do not discourage onsite electricity generation. A common finding in the second best literature studying multiple market failures is that more policy instruments capable of addressing different failures are often preferable to less (Allcott and Greenstone, 2012, Bennear and Stavins, 2007, Fischer and Newell, 2008, Goulder and Parry, 2008). Subsidies and informational provision 
for energy efficient $\mathrm{R} \& \mathrm{D}$ are also likely to be jointly ameliorating with the problem of pollution externalities. Perhaps environmental regulators can do a better job of selecting market based pollution regulation instruments that are also jointly ameliorating to the failures of the energy efficiency gap.

This paper is also related to the empirical literature studying the impact of the US EPA's National Ambient Air Quality Standards (NAAQS) on manufacturing activities. Such manufacturing studies typically use confidential US Census of Manufactures (CMF) data to study the impact of NAAQS on topics such as employment, sales, productivity, and compliance costs (e.g. Becker, 2005, Gray and Shadbegian, 1998, Greenstone, 2002, Greenstone et al., 2012, Levinson, 1996, Shadbegian and Gray, 2005, 2003). NOx RACT and RECLAIM are policies aimed at NAAQS nonattainment counties for ozone and nitrogen dioxide, but my study is different from previous studies using NAAQS and CMF data in a few key areas. First, the previous studies of NAAQS using CMF data generally focus on the early periods of the US Clean Air Act when NAAQS was first implemented in the 1970's. The NOx RACT and RECLAIM policies were ushered in with the 1990 amendments of the Clean Air Act, so the timeframe analyzed herein is much more recent. Second, this study identifies the actual manufacturing plants that are subject to NOx RACT and RECLAIM policies. This identification feature was not possible during the early period of NAAQS because the EPA did not start a national emissions inventory for stationary point sources of criteria pollutants prior to 1990. Finally, this is the first study to examine the impact of NAAQS related policies on the make or buy decision for electricity. Some recent studies have compared the heterogeneous impacts of NOx RACT and RECLAIM, but they do not use CMF data, and as a result the analyzed effects have generally been limited to analysis of emissions or industries other than manufacturing (e.g., Ferris et al., 2014, Fowlie et al., 2012). 
By analyzing the make or buy decision within manufacturing plants, the paper is also related to a large industrial organization literature regarding the determinants of vertical integration in firms. Studies of vertical integration can generally be classified as inter-firm studies or intra-firm studies. Inter-firm studies look at the make or buy decision across firms and typically measure the overall degree of vertical integration of production processes within a firm. As such, these inter-firm studies typically measure vertical integration with encompassing measures such as value added to sales ratios (see, for example, Balakrishnan and Wernerfelt, 1986, Levy, 1985, Tucker and Wilder, 1977). More recent empirical studies use an improved measure of vertical integration based on industry level input-output (IO) matrices and whether or not a firm owns establishments in downstream industries producing intermediate inputs (Acemoglu et al., 2010, Acemoglu et al., 2009, Aghion et al., 2006). Unlike value added measures, the improved IO based vertical integration measures do not conflate characteristics of profitability and horizontal integration with vertical integration. However, they also do not provide precise measures of the degree of vertical integration along an intensive margin.

Intra-firm studies of vertical integration typically consider the make or buy decision for a range of production processes within a given firm (Masten et al., 1989, Monteverde and Teece, 1982, Walker and Weber, 1984). These studies have an advantage in that they can precisely measure vertical integration of specific production processes, but they are often limited to analyzing the impacts of engineer's estimates of asset specificity on the likelihood of vertical integration. This paper is similar to both intra-firm and inter-firm studies because the unit of observation is individual facilities as opposed to production processes (as in inter-firm studies), and the degree of vertical integration of the specific electricity production process within a plant is precisely measured (as in intrafirm studies). The remainder of this study is organized as follows. Section 1 
provides an overview of the RECLAIM and NOx RACT regulatory policies relevant for manufacturing, and section 2 presents a theoretical model examining the heterogeneous impacts of cap-and-trade and command-and-control policies on vertical integration of polluting processes. Section 3 presents an overview of the CMF and NOx regulation data available for analysis, and section 4 provides estimates of the impact of NOx regulation on vertical integration decisions regarding electricity. Finally section 5 offers concluding comments.

\section{An Overview of NOx Policies}

The backbone of Title I of the US Clean Air Act (CAA) regulating industrial stationary source emissions is the establishment of National Ambient Air Quality Standards (NAAQS) for criteria pollutants $\left(\mathrm{NO}_{2}, \mathrm{SO}_{2}, \mathrm{~Pb}, \mathrm{CO}, \mathrm{O}_{3}\right.$, and $\left.\mathrm{PM}\right)$. US counties that fail to comply with NAAQS are designated as "nonattainment" and states must submit State Implementation Plans (SIPs) for plant-specific abatement at major sources of criteria pollutants in order to bring nonattainment counties into compliance with NAAQS (Greenstone, 2002). In terms of ozone $\left(\mathrm{O}_{3}\right)$, the EPA initially focused on controlling emissions of volatile organic compounds that were considered the limiting precursor. ${ }^{1}$ Existing stationary sources of NOx emissions we're unregulated by the EPA prior to the US Clean Air Act Amendments of 1990 (CAAA), and no county was designated nonattainment with NOx standards prior to 1990 (Burtraw and Evans, 2003).

The CAAA created three significant changes relevant for NOx regulation in the US. First, Title IV Section 407 of the CAA established NOx emission standards for utility boilers that we're enacted from 1995 to 1997. These emission standards we're part of the EPA's Acid Rain Program (ARP) than

\footnotetext{
${ }^{1}$ Historical control technique guidelines (CTGs) for VOC reduction technology are available in the EPA's SIP Planning Information Toolkit online repository:

http://www.epa.gov/groundlevelozone/SIPToolkit/ctgs.html (last accessed February, 2015).
} 
among other things established a cap-and-trade program for $\mathrm{SO}_{2}$ emissions. Manufacturing operated boilers are exempt from the Title IV requirements of the CAA, so the only impacts on manufacturing are indirect in the form of increased electricity market prices.

The second significant area of change with regards to NOx regulation that is relevant for manufacturing can be found in Title I of the CAA covering air pollution prevention. Section 182 (a)-(e) of Title I requires reasonably available control technology (RACT) for all "major sources" of VOC in ozone nonattainment counties to be implemented no later than May 31, 1995. Section 182 (a)-(b) and Section 302 define a major source as any source that has the potential to emit 100 tons per year (tpy) or more in marginal to moderate nonattainment counties. Section 182 (c)-(e) defines a major source as one with the potential to emit 50 tpy, 25 tpy, and 10 tpy in serious, severe, and extreme nonattainment counties, respectively. Furthermore, Section 182 (f) extends the RACT requirements to major sources of NOx in nonattainment areas, thereby regulating existing sources of NOx emissions for the first time in the US. The EPA has generally been flexible in terms of defining what constitutes RACT for NOx, but most state SIPs have relied on traditional command-and-control approaches (e.g. technology mandates and emissions standards) for specific polluting production processes (see EC/R Incorporated, 1995 for an overview of individual state NOx RACT policies).

A final important change for NOx regulation resulting from the 1990 CAAA is the creation of "Ozone Transport Regions" (OTRs) for the purpose of regulating cross-state ozone pollution. Section 184 of Title I of the CAA establishes an OTR consisting mostly of states in the Northeast Census region. ${ }^{2}$

\footnotetext{
${ }^{2}$ The OTR is comprised of the following states: Connecticut, Deleware, Maine, Maryland, Massachusetts, New Hampshire, New Jersey, New York, Pennsylvania, Rhode Island, Vermont, and the Districts of Columbia.
} 
According to the US Environmental Protection Agency (1992), attainment counties in states in the OTR are treated as moderate nonattainment thereby requiring NOx RACT for major sources emitting 100 tpy or more. As before, any nonattainment counties in the OTR may have more stringent regulations and lower thresholds for major source classification if they are designated serious nonattainment or worse.

In addition to the counties forced to regulate NOx emissions due to nonattainment of $\mathrm{O}_{3}$ NAAQS, four counties in California's South Coast Air Quality Management District (SCAQMD) were deemed to be nonattainment for $\mathrm{NO}_{2}$ NAAQS after the 1990 CAAA. $^{3}$ As noted above traditionally SIPs addressed NOx RACT requirements with technology mandates or emission standards specific to a major source's production processes (e.g. boilers, internal combustion engines, kilns and incinerators at facilities emitting 100 tpy or more). The California SIP to address NOx RACT requirements in the SCAQMD proposed an alternative cap-and-trade program for NOx emissions known as the Regional Clean Air Incentives Market (RECLAIM) to begin in 1994 (US Environmental Protection Agency, 2002). Under RECLAIM the EPA agreed that RACT could be met on an aggregate basis for the SCAQMD as long as total emissions were reduced by an amount at least as large as process-specific NOx RACT emission standards and technology mandates (South Coast Air Quality Management District, 2007). RECLAIM emissions trading began slowly with only 2,210 priced tons of NOx permit trades occurring in 1994 due in large part to an initial over-allocation of NOx allowances by the SCAQMD (South Coast Air Quality Management District, 1998). Trading volume doubled by 1996 and increased by a factor of 4 in 1997 . The average trading price for current year

\footnotetext{
${ }^{3}$ The nonattainment SCAQMD counties include Los Angeles, Orange, Riverside, and San Bernardino.
} 
NOx emissions was \$154 per ton and \$227 per ton during 1996 and 1997, respectively (Holland and Moore, 2012).

There are two key differences between the RECLAIM and ARP cap-andtrade systems that bear mentioning. First RECLAIM does not allow banking of unused permits beyond the current vintage year (Burtraw and Szambelan, 2009, Holland and Moore, 2012). Second, RECLAIM divides the SCAQMD into an upwind and downwind zone and only allows permit trades across zones in the direction of upwind to downwind in order to address the transport problem of ozone across zones (Burtraw and Szambelan, 2009). Aside from these differences, the RECLAIM cap-and-trade program operates similar to the national ARP cap-and-trade program in that it sets a cap on total emissions within the SCAQMD and allocates emission permits (that sum to the cap) to polluting firms on the basis of historical emissions. The section that follows provides a theoretical framework for analyzing incentives for manufacturing firms to vertically integrate the electricity production process under the alternative NOx RACT and RECLAIM regulatory schemes.

\section{Theory}

The profit function for a manufacturing firm currently producing their own electricity is given by the following:

$$
\pi_{i}=p^{*} f_{i}\left(L_{i}, K_{i}, E_{i}\right)-w^{*} L_{i}-r^{*} K_{i}-c^{*} E_{i}
$$

where $p$ is the price charged by firm i and $f_{i}(\cdot)$ is the firm's production function that depends on labor, $L_{i}$, capital, $K_{i}$, and energy inputs, $E_{i}$. The marginal cost of labor, capital, and energy are given by $w, r$, and $c$, respectively. Finally, the 
production function is assumed to be concave satisfying the following curvature and monotonicity conditions:

$$
\frac{d f(\cdot)}{d(\cdot)}>0
$$

$$
\frac{d^{2} f_{i}(\cdot)}{d(\cdot)^{2}} \leq 0
$$

Electricity generating manufacturing firms may choose comply with the NOx RACT emission standards and technology mandates by installing technology (e.g. low NOx burners and selective catalytic reduction) to reduce emissions or purchasing energy from the market at a price $e$ that is assumed to be strictly greater than $c$ when energy use is greater than zero. The profit for firm $\mathrm{i}$ procuring energy from the market is given by:

$$
\pi_{i}=p^{*} f_{i}\left(L_{i}, K_{i}, E_{i}\right)-w^{*} L_{i}-r^{*} K_{i}-e^{*} E_{i},
$$

Because emission standards are process-specific (i.e. boiler standards defined on an emission per heat-input basis) investments in energy efficiency that improve output per unit of energy are not going to be rewarded as an emission reducing activity. For simplicity in the analysis that follows it is assumed that installing the NOx reducing technology requires a fixed cost investment of $\$ F C$ but does not alter the marginal cost of energy denoted as $c$ in equation (1). Letting $\pi_{i}^{*}$ denote the maximized profit from equation (1) and $\pi_{i}^{* *}$ denote the maximized profit in equation (4) implies that the firm should install the low NOx technology and 
continue generating their own electricity as long as the following inequality is satisfied:

$$
\sum_{t=0}^{N} \frac{\pi_{i}^{*}-\pi_{i}^{* *}}{(1+r)^{t}} \geq \$ F C
$$

where $r$ is the interest rate or the rate of return on capital and $N$ is the expected life of the abatement technology. Stated alternatively, if the difference in discounted profits between self-generation and market procurement is less than the fixed cost of NOx abatement technology the firm should vertically disintegrate the electricity generation process. The curvature and monotonicity conditions in equations (2) and (3) are sufficient to ensure that $\pi_{i}^{*}>\pi_{i}^{* *}$, because profits are decreasing in energy costs. Note that in the absence of any changes along the intensive margin in energy use the left hand side of equation (5) simplifies to the discounted difference in total energy costs and results in an investment decision similar to the energy efficiency investment decision modeled in Allcott and Greenstone (2012). ${ }^{4}$

The profit maximization decision for an identical vertically integrated plant operating under California's RECLAIM cap-and-trade program for NOx emissions is given by the following:

$$
\pi_{i}=p^{*} f_{i}\left(L_{i}, K_{i}, E_{i}\right)-w^{*} L_{i}-r^{*} K_{i}-c^{*} E_{i},-m^{*}\left(X_{i} E_{i}-A_{0}\right),
$$

\footnotetext{
${ }^{4}$ This is an overly restrictive assumption that does not allow for the presence of rebound effects (see Bennear et al., 2013, Davis, 2008, and Greening et al., 2000 for examples of rebound effects in durable goods). Such a simplification may be justified in the presence of marginal cost pricing of electricity plants with a fixed markup if the marginal cost of energy use is the same for electric utilities and manufacturing firms.
} 
where all variables are defined as in equation (1) and the last term in equation (6) represents an additional cost per unit of emissions. As such, $m$ is the per-unit emission price and $X_{i}$ is an emission factor for firm i expressing units of NOx emissions per unit of energy input. Finally, NOx emission allowances are grandfathered under RECLAIM based on historic emission levels, and $A_{0}$ is the firm's initial allocation of emission permits. It is worth noting that if actual emissions are less than the initial permit allocation (i.e. $X_{i} E_{i}<A_{0}$ ) the firm will be a net seller of permits, and if actual emissions are greater than the initial permit allocation the firm will be a net buyer of tradable permits.

The marginal cost of energy in equation (6) is larger than the marginal cost in equation (1) by the amount $m X_{i}$. This feature of the cost structure makes it seem less likely that a firm will remain vertically integrated under a cap-and-trade regime in comparison to the likelihood of vertical integration under a regime using technology mandates or emission standards if the increased marginal cost is higher than market procurement energy prices. However, emission permits are allocated based on historic emissions, and if plants can reduce $X_{i}$ sufficiently to become a net seller of permits through technological pollution abatement investments the firm may be more likely to remain vertically integrated under the RECLAIM program. As an extreme example, suppose the available abatement technology can reduce the emission factor $X_{i}$ to 0 . As before, the firm operating under technology mandates installs the technology and remains vertically integrated as long as equation (5) is satisfied. Assuming electric utilities install the technology regardless of regulatory structure and energy prices, $e$, are the same in the technology mandate and cap-and-trade markets implies that a plant operating under cap-and-trade will install the abatement technology if the following is satisfied: 


$$
\sum_{t=0}^{N} \frac{\pi_{i}^{*}-\pi_{i}^{* *}+m A_{0}}{(1+r)^{t}} \geq \$ F C .
$$

Comparing equation (5) to equation (7) illustrates that manufacturing plants operating under cap-and-trade are more likely to install technology that results in complete abatement of emissions and remain vertically integrated due to the windfall gains from selling their initial allocation of pollution permits. Additionally, end-of-line plant-level emissions are priced under the capand-trade program, which provides a portfolio of profit maximization alternatives that are not incentivized under technology mandates (Goulder and Parry, 2008). Specifically, cap-and-trade creates incentives for the following alternative abatement strategies:

1. Plants may choose to invest in energy efficiency and increase the average productivity of energy, $\frac{f_{i}(\cdot)}{E_{i}}$, especially if such investments will reduce energy consumption to a level that the plant becomes a net seller of emission allowances.

2. Plants may choose to remain vertically integrated without installing abatement technology if the marginal cost of energy, $c+m X_{i}$, is less than the price of energy, $e$.

In sum, manufacturing plants operating under cap-and-trade as opposed to technology mandates appear more likely to invest in highly effective (low emission factor) pollution abatement technology and energy efficiency, and more likely to remain vertically integrated in pollution generating processes. This does of course assume that technology mandates are actively enforced, penalties for non-compliance are sufficiently high, cap-and-trade doesn't drive the marginal cost of energy above the market procurement price, and the cap on pollution 
emissions is binding. The following section presents an overview of the data available to test these theoretical predictions, and section 4 presents formal empirical tests.

\section{Data}

This paper merges environmental policy data from the US EPA and California's SCAQMD to confidential plant-level manufacturing data from the Census Bureau's Census of Manufactures (CMF). Plants subject to NOx RACT and RECLAIM oversight are identified based on the US EPA's and California EPA's historic emissions inventory for NOx..$^{5}$ The emissions inventory contains data on plant-level criteria pollutant emissions along with the plant name and address. RECLAIM plants consists of those located in the SCAQMD with annual NOx emissions of 4 tpy or more. NOx RACT plants are major sources emitting 100 tpy or more of NOx, and are located in non-attainment counties for ozone and/or the northeastern OTR. ${ }^{6}$ It would be ideal to identify all "major" sources subject to NOx RACT in serious or worse nonattainment counties, but the emissions reporting requirements prior to 2002 only require states to report disaggregated emissions for point sources emitting 100 tpy NOx or more (US Environmental Protection Agency, 1991, 2005).

A total of 119 RECLAIM, 188 OTR NOx RACT, and 492 non-OTR NOx RACT plants from the emissions inventories were identified as regulatory program participants based on the criteria outlined above. The EPA emissions inventory contains address data for regulated plants, but it is important to note that

\footnotetext{
${ }^{5}$ The US EPA's historic emission inventory is available at http://www.epa.gov/ttn/chief/net/critsummary.html (last accessed 3/1/2015). The California EPA's emissions inventory is available at http://www.arb.ca.gov/ei/disclaim.htm (last accessed 3/1/2015).

${ }^{6}$ Historic nonattainment data is available from the EPA's Green Book, and is available for download at: http://www.epa.gov/airquality/greenbook/data_download.html.
} 
roughly $42 \%$ of NOx RACT participants have missing address data in the US EPA's emissions inventory. Because accurate address data is vital for accurately matching the environmental policy data to CMF data, missing addresses were reconciled with the EPA's Facility Registry Service (FRS) and google maps address data based on available latitude, longitude, city and state. ${ }^{7}$ After supplementing emission inventory address data with the FRS addresses only 4\% of the NOx RACT plants were left with missing addresses.

The environmental policy data was matched to the Census Bureau's Longitudinal Business Database (LBD), which is a longitudinally linked Standard Statistical Establishment List (SSEL) containing information on manufacturing plants' name and address. SAS's DQMATCH routine was used to standardize the data and match the external environmental policy data with the LBD by manufacturing plant name and address. ${ }^{8}$ The DQMATCH routine was first used to match the data based on all available name and address criteria (i.e. plant name, street address, city, state, and zip). Possible matches identified by DQMATCH were cross-validated manually by the researcher to ensure accurate matches, and the data was parsed several times in order to test for possible matches with less stringent match criteria (e.g. name and city matching only). Once the environmental policy data is matched to the LBD it is easily matched to the CMF data via a longitudinal business database number (lbdnum) that is a unique timeinvariant plant identifier that allows individual plants to be tracked over time. The CMF data contains important information on plant-level electricity generation, and the subsection that follows provides a detailed overview of the CMF data used herein.

\section{A. Census of Manufactures}

\footnotetext{
${ }^{7}$ The FRS database is available online at http://www.epa.gov/enviro/html/fii/index.html (last accessed 3/1/2015).

${ }^{8}$ For an overview of the DQMATCH routine see SAS Institute (2008).
} 
The CMF is a census of all US manufacturing plants, and the confidential data is available to researchers with special sworn status at Census Research Datacenters beginning with data from 1967 . The CMF is conducted every 5 years for years ending in 2 or 7, and provides detailed data on manufacturing plant characteristics such as the following: total value of shipments, cost of materials, number of employees, employee hours worked, single/multi- unit plant classification, and electricity and energy consumption/production. In off CMF years the Census Bureau conducts an Annual Survey of Manufactures (ASM) that collects much of the same data collected in the CMF for a subset of manufacturing establishments. Larger establishments with 1,000 or more employees or ranking in the top ten among the industry in terms of total value of shipments are surveyed with certainty, and smaller establishments are surveyed using probability weighting that adjusts for the establishment's contribution to industry output totals. ${ }^{9}$

The analysis conducted herein focuses on the NOx regulation of the early 1990s and uses CMF data from 1992 and 1997 supplemented with ASM data from 1993 to 1996. The 1992 to 1997 period was chosen to avoid overlap with changing NAAQS standards and electricity deregulation in California. Specifically, the 1992 to 1997 time period was chosen for the following reasons:

1. With the exception of NOx, there we're no new NAAQS standards for criteria pollutants promulgated and enforced during this time period.

2. Although it is possible for NAAQS nonattainment counties to be reclassified as attainment during this time period, states must submit maintenance plans to prevent environmental degradation in order to be granted reclassification. As a result reclassification in the direction nonattainment $\rightarrow$ attainment is not likely to result in reduced oversight and enforcement.

\footnotetext{
${ }^{9}$ See http://www.census.gov/manufacturing/asm/how_the_data_are_collected/index.html (last accessed 3/1/2015), for an overview of the selection criteria for the ASM.
} 
3. In 1998 the provisions of California's Electric Utility Industry Restructuring Act for deregulating electricity production were implemented, and by mid2000 California faced an electricity crisis with rising electricity prices (Farmer et al., 2001, Joskow, 2001).

In addition to limiting the timeframe of analysis to the six year period 1992 to 1997, the analysis that follows focuses on the following four industries: Paper and Pulp (SIC 26), Chemicals (SIC 28), Petroleum Refining (SIC 29), and Primary Metals (SIC 33). These four industries collectively account for $94 \%$ of all generated electricity in manufacturing. ${ }^{10}$ Summary statistics for the CMF data are provided in Table I for the four industries and other manufacturing industries, respectively. Establishments in the four industries are larger on average than other manufacturing establishments in terms of total value of shipments, cost of materials, and labor input. Manufacturing plants in the four industries are more likely to be multi-unit plants $(46 \%)$ than plants in other manufacturing industries (16\%), and plants in the four industries have a more productive workforce. Overall, the summary statistics for "other" manufacturing establishments are generally closer to the averages for all manufacturing industries given in the last column of Table I. This feature of the data is due to the fact that establishments in the four industries account for only $7.8 \%$ of total manufacturing establishments.

The last six rows of Table I provide summary statistics for the energy variables that are of primary importance to the research conducted herein. First, energy productivity is constructed as the price deflated total value of shipments divided by the total British thermal units (Btus) of energy input used at the plant. The price deflator used is the industry specific output deflator from the NBERCES Manufacturing Industry Database (see, Becker et al., 2013). The CMF collects detailed information on electricity purchases measured in kilowatt-hours

\footnotetext{
${ }^{10}$ In the remainder of the paper when a reference is made to the "four industries" it is referring to the industries listed here.
} 
$(\mathrm{kWh})$, and these purchases are converted to Btus using the US Energy Information Administration's (EIA) conversion factor of 3.412 Btu per 1,000 $\mathrm{kWh}$ electricity. Additional energy input comes in the form of raw fuels that are consumed during the manufacturing process. The CMF collects data on the total cost of these raw fuel inputs, but does not collect data on the fuel mixture or fuel prices necessary to convert cost of fuels to Btu. In order to convert cost of fuels to Btu input it is assumed that manufacturing plants are using natural gas for their fuel input. This is a reasonable assumption, because according to the EIA's Manufacturing Energy Consumption Survey in 1994 and 1998 70\% to $73 \%$ of all purchased fuels in manufacturing are natural gas. ${ }^{11}$ Data on natural gas prices is available from the EIA at the state and year level for industrial consumers. ${ }^{12}$ Dividing the plant's cost of fuels by natural gas prices converts the costs to cubic feet of natural gas, and cubic feet are converted to Btu using the EIA's conversion factor of 1.022 Btu per 1,000 cubic foot of natural gas. Plants in the four industries are less productive on average in terms energy productivity than the plants in other manufacturing industries.

Lower energy productivity in the four industries may simply be due to the fact that these industries are much more energy intensive than other manufacturing industries. The average plant in the four industry sample generates 3.3 million $\mathrm{kWh}$ of electricity each year, and the average plant in the other manufacturing industries generates less than $20,000 \mathrm{kWh}$ of electricity annually. Stated alternatively, plants in the four industry sample generate over 200 times the amount of electricity as plants in the other manufacturing industries. Similarly, plants in the four industry sample purchase roughly 12 times the amount of

\footnotetext{
${ }^{11}$ A summary of the MECS survey is available online at www.eia.gov/consumption/manufacturing (last accessed 3/6/2016).

${ }^{12}$ Natural gas price data is available online at http://www.eia.gov/dnav/ng/ng_pri_sum_dcu_nus_m.htm (last accessed 3/1/2015).
} 
electricity purchased in other manufacturing industries and account for $48 \%$ of all purchased electricity in manufacturing.

The last row in Table I provides data on the key outcome variable of interest measuring the degree of vertical integration of the electricity generating process in the plant. As expected plants in the four industries are much more vertically integrated in electricity production, and roughly $18 \%$ of the total electricity used is generated onsite. Plants in other manufacturing industries generate only $1 \%$ of their electricity on average.

Table II provides additional characteristics for the four industries separately, and illustrates that there is considerable heterogeneity by industry in the dataset. The profit margins are similar across industries, but the Petroleum Refining (SIC 29) industry has considerably larger revenues and costs than the other industries analyzed. The Primary Metal (SIC 33) industry and the Paper and Pulp (SIC 26) industry employ more workers and production workers on average, but are the least productive in terms of labor and energy productivity. Most of the industries are between $50 \%$ and $60 \%$ single-unit establishments, but $64 \%$ of the establishments in the Petroleum Refining industry are actually multi-unit establishments. The Primary Metal industry generates the least amount of electricity among the four industries considered and purchases the largest amount of electricity. As a result roughly $4 \%$ of the electricity used in the Primary Metal industry is vertically integrated. Indeed, the last row of Table II illustrates that there is considerable heterogeneity across industries in terms of the vertical integration of electricity. Roughly $39 \%$ of electricity is generated in the Pulp and Paper industry, $15 \%$ is generated in the Chemical industry (SIC 28), and $19 \%$ of electricity is generated in Petroleum Refining. The following section presents the econometric models and results analyzing the impact of heterogeneous NOx regulatory policies on the vertical integration of electricity generation in these four manufacturing industries. 


\section{Empirical Analysis}

In order to estimate the impact of NOx regulation on manufacturing plants' decision to vertically integrate the electricity generating process, the following plant fixed effects model is estimated:

$$
V I_{p, t}=a+P R_{p, t} \partial+N O X_{p, t} \beta+T_{t}+P_{p}+I_{p} * T_{t}+\varepsilon_{p, t} \cdot
$$

In equation (8) the vertical integration, $V I_{p, t}$, of electricity generation at plant $\mathrm{p}$ and time $\mathrm{t}$ is a function of a vector of energy prices, $P R_{p, t}$, that include market electricity prices and natural gas prices, plant fixed effects, $P_{p}$, and year fixed effects, $T_{t}$. Equation (8) also includes 4-digit SIC indicator variables, $I_{p}$, interacted with year effects in order to allow for industry specific time trends, and a random error term, $\varepsilon_{p, t}$, that is clustered at the plant-level to control for arbitrary inter-temporal correlation within plants. Finally, $N O X_{p, t}$ is a vector of NOx regulation indicator variables that includes controls for RECLAIM and NOx RACT program participation. The RECLAIM indicator variable is equal to 1 for program participants in 1995 and each year subsequent to 1995. Similarly, the NOx RACT indicator variable is equal to 1 for plants regulated by NOx RACT in 1996 and 1997. ${ }^{13}$ As such, the vector of estimated coefficients $\beta$ for the $N O X_{p, t}$ indicators are the key coefficients of interest that identify the impact of RECLAIM and NOx RACT on the degree of vertical integration of electricity in manufacturing.

As mentioned in the data section equation (8) is estimated over the years 1992 to 1997 for four 2-digit SIC industry classifications that collectively account for $94 \%$ of all generated electricity in manufacturing. The timeframe for analysis

\footnotetext{
${ }^{13}$ Alternative specifications set the RECLAIM and NOx RACT indicator variables equal to 1 in the first partial years of regulation 1994 and 1995, respectively. The results are robust to choice of program start date.
} 
was chosen to avoid conflation with changing NAAQS standards and the deregulation of electricity markets and subsequent energy crisis in California. Singleton observations that only appear once during the 1992 to 1997 time frame are dropped from the analysis due to time-demeaning the data. The 1992 and 1997 CMF data are supplemented with ASM data in non-CMF years and the resulting panel consists of roughly 59,600 observations of 16,100 individual plants.

Results from the estimation of equation (8) are presented in Table III for two specifications. Column 1 of Table III presents results for the model specified exactly as in equation (8). California's RECLAIM cap-and-trade program for NOx has no statistically significant effect on vertical integration at any conventional level of significance. In both specifications presented in Table III, we fail to reject the null hypothesis that the estimated coefficient for RECLAIM is statistically indistinguishable from zero at a significance level of $30 \%$ or more. The only statistically significant factor explaining plants' decisions to vertically integrate is participation in the EPA's traditional command-and-control NOx RACT program. This effect is statistically significant at the $1 \%$ level, and suggests that participation in NOx RACT is associated with a 3.1 percentage point reduction in vertical integration. These results are consistent with the theoretical model presented in section 2 that predicted a negative impact of command-andcontrol policy on vertical integration and a theoretically ambiguous impact of a cap-and-trade regulatory approach. Because RECLAIM has no statistically significant impact on vertical integration, it is likely that the cap-and-trade program is not driving marginal electricity generation costs higher than market electricity prices. This feature is not surprising given that manufacturing facilities and electric utilities in the SCAQMD both participate in RECLAIM and pay/receive the same price for NOx tradable permits. 
The results in column 2 of Table III are for an alternative specification that includes all of the variables as specified in equation (8) along with the timevarying plant characteristics listed in Table I. Results from this alternative specification suggest that a $\$ 100$ million increase in the deflated total value of shipments is associated with a 0.31 percentage point increase in the likelihood of vertical integration and the effect is significant at the 10 percent level. This suggests that larger plants are more likely to integrate electricity generation, but the remaining plant characteristics listed in Table I are statistically insignificant predictors of vertical integration. Furthermore, inclusion of the time varying plant characteristics has no appreciable impact on the key coefficients of interest measuring the impact of NOx regulation.

\section{A. Robustness}

In order to identify the average treatment effect for treated plants, the fixed effects model presented in equation (8) assumes that the time-demeaned vertical integration decisions for RECLAIM and RACT program participants follow a common trend with the decisions of untreated plants in the absence of any NOx regulation. In order to test whether this is a reasonable assumption and obtain a more comprehensive understanding of the transition dynamics of NOx regulated plants the following event study is estimated:

$$
\begin{aligned}
& V I_{p, t}=a+P R_{p, t} \partial+\sum_{n=1992}^{1997} \gamma_{n} I\left[\operatorname{RECY}_{p, t}=n\right]+ \\
& \sum_{n=1992}^{1997} \lambda_{n} I\left[R A C Y_{p, t}=n\right]+T_{t}+P_{p}+I_{p} * T_{t}+\varepsilon_{p, t},
\end{aligned}
$$

where all variables are as defined in equation (8), except $R E C Y_{p, t}$ and $R A C Y_{p, t}$ are equal to the observation year for RECLAIM and NOx RACT program participants, respectively, and equal to zero for non-participants. $I[\cdot]$ is an 
indicator function that is equal to 1 for NOx regulation program participants in year $\mathrm{n}$ and equal to zero otherwise. The omitted reference program year is one year prior to program implementation for both NOx policies (i.e. I[REC $\left.Y_{p, t}=1994\right]$ and I[RACY $\left.Y_{p, t}=1995\right]$ are omitted).

The estimated coefficients on the time trends for program participants, $\gamma_{n}$ and $\lambda_{n}$ in equation (9), are presented in Figures 1 and 2 for RECLAIM participants and NOx RACT participants, respectively. The estimated coefficients for RECLAIM participants are statistically indistinguishable from zero for all years pre- and post-1994. These results are consistent with the idea that RECLAIM participants are not changing their vertical integration decisions before or after the program implementation. Similarly, the NOx RACT time trends indicate there is no significant difference in vertical integration behavior prior to the treatment period, but there is a stable significant reduction in vertical integration in the posttreatment years 1996 to 1997 that is comparable to the estimated coefficient on the NOx RACT indicator variable in the fixed effect model of equation (8).

In order to gain a better understanding of the methods by which NOx policies affect vertical integration several alternative dependent variables are also considered for the specification given in equation (8). First, an alternative indicator variable of vertical integration is considered in which a plant is considered vertically integrated (i.e. $V I_{p, t}=1$ ) if it generates any electricity used in production, and not vertically integrated otherwise. This measure of vertical integration is only going to capture changes along the extensive make or buy margin. The results of the specification using the alternative vertical integration indicator variable are presented in column 1 of Table IV. The estimated coefficient on the NOx RACT indicator variable remains statistically significant at the $1 \%$ level, and is similar in magnitude to the results from equation (8) using the continuous vertical integration term. In Table IV, NOx RACT is estimated to reduce the likelihood of generating any electricity by 4.5 percentage points. 
Interestingly, column 1 in Table IV also indicates that RECLAIM reduces vertical integration along the extensive margin by 5.1 percentage points, and the effect is weakly significant at the $10 \%$ level.

These results combined with the results from Table III suggest that smaller electricity generators may decide to stop generating electricity under cap-andtrade, but the effect is not pervasive enough to generate a statistically significant impact on overall vertical integration. A possible explanation for this behavior is that smaller generators may not be large enough to justify investment in NOx abatement technology and the increase in marginal cost from RECLAIM drives costs above market electricity prices for small generators. This seems particularly likely given the fact that RECLAIM has a much lower NOx emission threshold for program participation than the NOx RACT program.

It is also worthwhile to determine whether it is changes in purchased electricity or generated electricity that are driving the results of equation (8). In order to investigate this question, columns 2 and 3 of Table IV present results for the following equations:

$$
\begin{aligned}
& \ln \left(P E_{p, t}\right)=a+P R_{p, t} \partial+N O X_{p, t} \beta+T_{t}+P_{p}+I_{p} * T_{t}+\varepsilon_{p, t}, \\
& \ln \left(T E_{p, t}\right)=a+P R_{p, t} \partial+N O X_{p, t} \beta+T_{t}+P_{p}+I_{p} * T_{t}+\varepsilon_{p, t},
\end{aligned}
$$

where all variables are defined as in equation (8) except the natural log of purchased electricity use, $P E_{p, t}$, and the natural $\log$ of total electricity use, $T E_{p, t}$, are the dependent variables of interest. The results from Table IV suggest that plants regulated by NOx RACT are less vertically integrated due to reductions in generated electricity rather than increases in purchased electricity. Specifically, NOx RACT results in no statistically significant changes in purchased electricity, but total electricity consumption (generated + purchased) is estimated to decline 
by $6.7 \%$ and the effect is significant at the $10 \%$ level. The only other significant variables explaining electricity use in equations (10) and (11) are electricity prices, and the sign of the coefficient on electricity prices is of the a priori expected direction. A $\$ 1.00$ increase in the price of $1,000 \mathrm{kWh}$ of electricity is estimated to reduce purchased electricity and total electricity use by $23 \%$ approximately.

Finally, the theoretical model presented in section 2 suggests that RECLAIM program participants may choose to reduce NOx emissions through investments in energy efficiency in addition to or in place of investments in abatement technology and changes in output. The abatement technology mandates and emission standards enforced under NOx RACT, however, do not provide incentives for investments in energy efficiency. In order to analyze the impact of NOx policies on energy efficiency the following equation is estimated:

$$
\ln \left(E P_{p, t}\right)=a+P R_{p, t} \partial+N O X_{p, t} \beta+T_{t}+P_{p}+I_{p} * T_{t}+\varepsilon_{p, t},
$$

where all variables are defined as in equation (8) except the dependent variable of interest is now the natural log of energy productivity as defined in section 3 and Table I. Results from the estimation of equation (12) are presented in column 4 of Table IV, and suggest that RECLAIM participants increase the average productivity of energy by $22 \%$ in response to NOx regulation. Interestingly, the average energy productivity at NOx RACT plants declines by $4 \%$ post regulation. One possible explanation for this decline in productivity at NOx RACT plants is that abatement technology such as low NOx burners (LNB) or selective catalytic reduction (SCR) does not increase output and may generate less steam in the case of LNB or require energy to operate in the case of SCR (US Environmental Protection Agency, 1999). 


\section{Conclusion}

This research estimates the impact of heterogeneous NOx regulatory regimes on distributed electricity generation in manufacturing. Theoretically manufacturing plants are less likely to vertically integrate the electricity generating process under command-and-control NOx regulation in comparison to unregulated plants. The impact of cap-and-trade NOx regulation has a theoretically ambiguous impact on vertical integration decisions, because it increases the marginal cost of electricity generation and also can increase revenues if firms are able to cut emissions below their grandfathered NOx emission permit allocation.

In order to obtain an empirical estimate of the impact of alternative NOx policies on vertical integration the paper combines confidential US Census of Manufactures (CMF) data with plant-level NOx regulation data from the US EPA and California's ARB for the years 1992 to 1997. The EPA data includes an indicator for manufacturing plants' participation in the Reasonably Available Control Technology (RACT) NOx regulatory program that relies on typical command-and-control policies of process specific emissions limits and NOx abatement technology mandates. Similarly the ARB data measures plants' participation in California's Regional Clean Air Incentives Market (RECLAIM), which is a NOx emission cap-and-trade alternative to the NOx RACT program.

For the NOx RACT policy, results indicate that vertical integration of electricity decreases by 3.1 percentage points as measured along the intensive margin, and the likelihood of a manufacturing plant generating any electricity is reduced by 4.5 percentage points. The estimated reductions in electricity generation due to NOx RACT are statistically significant at the $1 \%$ level. The

effects of RECLAIM vary by measurement of vertical integration, and the intensive measure finds no statistically significant effect at any conventional 
significance level. However, on the extensive margin RECLAIM is estimated to reduce the likelihood of generating any electricity by 5.1 percentage points and the effect is significant at the $10 \%$ level. Taken together these results suggest that RECLAIM may induce some plants to switch from electricity generation to market procurement, but this effect is only likely to impact small generators.

In addition to the impact on vertical integration, RECLAIM is estimated to result in increased investment in energy efficiency. These energy efficiency investments result in a $22 \%$ increase in average energy productivity at RECLAIM plants. In comparison, NOx RACT plants experience a $4 \%$ decline in average energy productivity because process specific NOx regulations do not incentivize investments in energy efficiency of upstream production processes.

In sum, cap-and-trade regulatory policies are likely to have a smaller impact on distributed electricity generation than command-and-control alternatives, and are more likely to encourage investments in energy efficiency. A cap-and-trade system affords regulated firms flexibility in choosing the least-cost compliance alternatives by incentivizing improvements in energy consumption and emissions. At the aggregate level the efficiency gains from cap-and-trade are more apparent, because Shipley, Hampson, Hedman, Garland and Bautista (2008) estimate that $6-8 \%$ of generated electricity is lost during transmission. These transmission losses are avoided with distributed generation where electricity is produced at the point of consumption, but command-and-control approaches reduce the degree of distributed generation employed in manufacturing.

A worrisome feature of recent US environmental regulation has been a shift away from the market based cap-and-trade regulations popularized in the 1990's towards an older command-and-control approach (Schmalensee and Stavins, 2013). New EPA proposals to regulate $\mathrm{CO}_{2}$ emissions are based on emissions standards that require emissions for electricity generating units to be below a rate measured in lbs. of $\mathrm{CO}_{2}$ per MWh of electricity (US Environmental 
Protection Agency, 2014a, b). In their current form, however, these new emission standard proposals recognize the benefits of distributed generation in reducing transmission losses by exempting manufacturing units from regulation as long as they contribute less than $1 / 3$ of their generated electricity to the grid. In addition, the federal government and several states have recently implemented policies to reduce emissions through the improved energy efficiency of distributed generation. These policies are typically subsidies for combined heat and power applications, and an overview of federal and state policies is available from the US EPA's CHP Policies and Incentives Database. ${ }^{14}$ Although these new regulatory approaches are an improvement over emissions standards of old, they still are inefficient in the sense that they do not equate marginal abatement costs across polluting sources.

\section{References}

Acemoglu, Daron; Rachel Griffith; Philippe Aghion and Fabrizio Zilibotti. 2010. "Vertical Integration and Technology: Theory and Evidence." Journal of the European Economic Association, 8(5), 989-1033.

Acemoglu, Daron; Simon Johnson and Todd Mitton. 2009. "Determinants of Vertical Integration: Financial Development and Contracting Costs." The Journal of Finance, 64(3), 1251-90.

Aghion, Philippe; Rachel Griffith and Peter Howitt. 2006. "Vertical Integration and Competition." The American economic review, 97-102.

Allcott, Hunt and Michael Greenstone. 2012. "Is There an Energy Efficiency Gap?" The Journal of Economic Perspectives, 3-28.

\footnotetext{
${ }^{14}$ Available online: http://www.epa.gov/chp/policies/database.html (last accessed 3/3/2015).
} 
Balakrishnan, Srinivasan and Birger Wernerfelt. 1986. "Technical Change, Competition and Vertical Integration." Strategic Management Journal, 7(4), 34759.

Becker, Randy A. 2005. "Air Pollution Abatement Costs under the Clean Air Act: Evidence from the Pace Survey." Journal of environmental economics and management, 50(1), 144-69.

Becker, Randy; Wayne Gray and Jordan Marvakov. 2013. "Nber-Ces Manufacturing Industry Database: Technical Notes," Technical report, National Bureau of Economic Research,

Bennear, Lori S; Jonathan M Lee and Laura O Taylor. 2013. "Municipal Rebate Programs for Environmental Retrofits: An Evaluation of Additionality and CostEffectiveness." Journal of Policy Analysis and Management, 32(2), 350-72.

Bennear, Lori Snyder and Robert N Stavins. 2007. "Second-Best Theory and the Use of Multiple Policy Instruments." Environmental and Resource Economics, 37(1), 111-29.

Burtraw, Dallas and David A Evans. 2003. "The Evolution of Nox Control Policy for Coal-Fired Power Plants in the United States."

Burtraw, Dallas and Sarah Jo Fueyo Szambelan. 2009. "Us Emissions Trading Markets for So2 and Nox." Resources for the Future Discussion Paper, (09-40).

CAA. 1970. "Clean Air Act Extension of 1970," P. L. 91-604, 84 Stat. 1676.

CAAA. 1990. "Clean Air Act Amendments of 1990," P. L. 101-549, 104 Stat. 2399.

Coase, Ronald Harry. 1960. "Problem of Social Cost, The." JL \& econ., 3, 1.

Dales, JH. 1968. Pollution Property and Prices. University of Toronto Press.

Davis, Lucas W. 2008. "Durable Goods and Residential Demand for Energy and Water: Evidence from a Field Trial." The RAND Journal of Economics, 39(2), 530-46.

EC/R Incorporated. 1995. "Summary of State Nox Ract Rules," US Environmental Protection Agency, 1-56. 
Farmer, Richard; Dennis Zimmerman and Gail Cohen. 2001. "Causes and Lessons of the California Electricity Crisis," Congress of the United States Congressional Budget Office, 1-33.

Ferris, Ann E; Ronald J Shadbegian and Ann Wolverton. 2014. "The Effect of Environmental Regulation on Power Sector Employment: Phase I of the Title Iv So2 Trading Program." Journal of the Association of Environmental and Resource Economists, 1(4), 521-53.

Fischer, Carolyn and Richard G Newell. 2008. "Environmental and Technology Policies for Climate Mitigation." Journal of environmental economics and management, 55(2), 142-62.

Fowlie, Meredith; Stephen P Holland and Erin T Mansur. 2012. "What Do Emissions Markets Deliver and to Whom? Evidence from Southern California's Nox Trading Program." The American economic review, 102(2), 965-93.

Goulder, Lawrence H and Ian WH Parry. 2008. "Instrument Choice in Environmental Policy." Review of Environmental Economics and Policy, 2(2), 152-74.

Gray, Wayne B and Ronald J Shadbegian. 1998. "Environmental Regulation, Investment Timing, and Technology Choice." The Journal of Industrial Economics, 46(2), 235-56.

Greening, Lorna A; David L Greene and Carmen Difiglio. 2000. "Energy Efficiency and Consumption - the Rebound Effect - a Survey." Energy policy, 28(6), 389-401.

Greenstone, Michael. 2002. "The Impacts of Environmental Regulations on Industrial Activity: Evidence from the 1970 and 1977 Clean Air Act Amendments and the Census of Manufactures." Journal of political economy, 110(6), 1175219. 
Greenstone, Michael; John A List and Chad Syverson. 2012. "The Effects of Environmental Regulation on the Competitiveness of Us Manufacturing," National Bureau of Economic Research,

Holland, Stephen P and Michael Moore. 2012. "When to Pollute, When to Abate? Intertemporal Permit Use in the Los Angeles Nox Market." Land Economics, $88(2), 275-99$.

Joskow, Paul L. 2001. "California's Electricity Crisis." Oxford Review of Economic Policy, 17(3), 365-88.

Levinson, Arik. 1996. "Environmental Regulations and Manufacturers' Location Choices: Evidence from the Census of Manufactures." Journal of Public Economics, 62(1), 5-29.

Levy, David T. 1985. "The Transactions Cost Approach to Vertical Integration: An Empirical Examination." The Review of Economics and Statistics, 438-45.

Lipsey, Richard G and Kelvin Lancaster. 1956. "The General Theory of Second Best." The review of economic studies, 11-32.

Masten, Scott E; James W Meehan and Edward A Snyder. 1989. "Vertical Integration in the Us Auto Industry: A Note on the Influence of Transaction Specific Assets." Journal of Economic Behavior \& Organization, 12(2), 265-73.

Monteverde, Kirk and David J Teece. 1982. "Supplier Switching Costs and Vertical Integration in the Automobile Industry." The Bell Journal of Economics, 206-13.

Pigou, AC. 1920. "The Economics of Welfare," London:

SAS Institute. 2008. Sas Data Quality Server 9.2: Reference. SAS Institute.

Schmalensee, Richard and Robert N Stavins. 2013. "The So 2 Allowance Trading System: The Ironic History of a Grand Policy Experiment." Journal of Economic Perspectives, 27(1), 103-22.

Shadbegian, Ronald J and Wayne B Gray. 2005. "Pollution Abatement Expenditures and Plant-Level Productivity: A Production Function Approach." Ecological Economics, 54(2), 196-208. 
. 2003. "What Determines Environmental Performance at Paper Mills? The Roles

of Abatement Spending, Regulation, and Efficiency." Topics in economic analysis \& policy, 3(1).

\section{Shipley, Anna; Anne Hampson; Bruce Hedman; Patti Garland and Paul}

Bautista. 2008. "Combined Heat and Power: Effective Energy Solutions for a Sustainable Future," Department of Energy, Oak Ridge National Laboratory, South Coast Air Quality Management District. 2007. "Over a Dozen Years of Reclaim Implementation: Key Lessons Learned in California's First Air Pollution Cap-and-Trade Program." . 1998. "Reclaim Program Three-Year Audit and Progress Report,"

Tucker, Irvin B and Ronald P Wilder. 1977. "Trends in Vertical Integration in the Us Manufacturing Sector." The Journal of Industrial Economics, 81-94.

US Environmental Protection Agency. 2014a. "Carbon Pollution Emission Guidelines for Existing Stationary Sources: Electric Utility Generating Units," 79 FR 34829.

. 1991. "Emission Inventory Requirements for Ozone State Implementation Plans," Research Triangle Park, NC: Office of Air Quality Planning and Standards Emission Inventory Branch Technical Support Division and Radian Corp.,, 1-68. . 2005. "Emissions Inventory Guidance for Implementation of Ozone and Particulate Matter National Ambient Air Quality Standards (Naaqs) and Regional Haze Regulations," Office of Air Quality Planning and Standards Emissions Inventory Group, 1-67. . 2002. "An Evaluation of the South Coast Air Quality Management District's Regional Clean Air Incentives Market - Lessons in Environmental Markets and Innovation." . 2014b. "Standards of Performance for Greenhouse Gas Emissions from New Statiionary Sources: Electric Utility Generating Units," 79 FR 1429. 
. 1992. "State Implementation Plans; Nitrogen Oxides Supplement to the General Preamble for the Implementation of Title I of the Clean Air Act Amendments of 1990," Federal Register, 40 CFR Part 52, 55620.

. 1999. "Technical Bulletin: Nitrogen Oxides (Nox) Why and How They Are Controlled," Research Triangle Park, NC: Office of Air Quality Planning and Standards,

Walker, Gordon and David Weber. 1984. "A Transaction Cost Approach to Makeor-Buy Decisions." Administrative science quarterly, 373-91. 
Table I. Average Employment, Energy, and Plant Characteristics (1997). ${ }^{1}$

\begin{tabular}{|c|c|c|c|c|}
\hline Variable Name & Description & $\begin{array}{c}\text { Four } \\
\text { Industries }\end{array}$ & $\begin{array}{c}\text { Other } \\
\text { Manuf. }\end{array}$ & $\begin{array}{c}\text { All } \\
\text { Manuf. }\end{array}$ \\
\hline Total Value of Shipments & $\begin{array}{l}\text { Total value of all products shipped by a plant, measured } \\
\text { in \$millions. }\end{array}$ & 34.3 & 8.7 & 10.6 \\
\hline Cost of Materials & $\begin{array}{l}\text { Total cost of all materials consumed or put into } \\
\text { production for the year, measured in \$millions. }\end{array}$ & 19.3 & 4.5 & 5.6 \\
\hline Number of Employees & $\begin{array}{l}\text { Annual average of total employees reported per quarter, } \\
\text { per plant. }\end{array}$ & 81.7 & 43.5 & 46.3 \\
\hline $\begin{array}{l}\text { Total Hours Worked By } \\
\text { Production Workers }\end{array}$ & $\begin{array}{l}\text { Total annual hours worked by production workers, } \\
\text { measured in thousands. }\end{array}$ & 120.2 & 62.4 & 66.7 \\
\hline Single Unit Plant & $\begin{array}{l}\text { Dummy variable equal to } 1 \text { for plants that are single } \\
\text { unit establishment and equal to zero for multi-unit } \\
\text { establishments. }\end{array}$ & $56 \%$ & $84 \%$ & $82 \%$ \\
\hline $\begin{array}{l}\text { Labor Productivity } \\
(\$ 1997)\end{array}$ & $\begin{array}{l}\text { Deflated total value of shipments divided by production } \\
\text { workers' total hours worked. }\end{array}$ & 285.7 & 139.3 & 158.6 \\
\hline $\begin{array}{l}\text { Energy Productivity } \\
(\$ 1997)\end{array}$ & $\begin{array}{l}\text { Deflated total value of shipments divided by total Btu } \\
\text { of energy input. }\end{array}$ & 666.1 & $1,999.3$ & $1,354.8$ \\
\hline Electricity Price & $\begin{array}{l}\text { Price of electricity measured in dollars per thousand } \\
\text { kilowatt hour }(\mathrm{kWh}) \text {. }\end{array}$ & 38.7 & 54.3 & 46.8 \\
\hline Natural Gas Price ${ }^{2}$ & Price of natural gas measured in dollars per cubic foot. & 3.6 & 3.6 & 3.6 \\
\hline Generated Electricity & Millions of $\mathrm{kWh}$ generated at the plant. & 3.3 & 0.02 & 0.3 \\
\hline Purchased Electricity & Millions of purchased kWh. & 15.1 & 1.3 & 2.3 \\
\hline Vertical Integration & Share of total electricity that is generated onsite. & $18 \%$ & $1 \%$ & $10 \%$ \\
\hline
\end{tabular}


Table II: Characteristics by SIC Classification (1997). ${ }^{1}$

SIC 26: SIC 28: $\quad$ SIC 29: SIC 33: Paper and Chemicals Petroleum Primary Pulp Refining Metal

Variable Name

\begin{tabular}{lcccc}
\hline $\begin{array}{l}\text { Total Value of Shipments } \\
\text { (\$millions) }\end{array}$ & 25.6 & 30.8 & 82.7 & 33.2 \\
Cost of Materials (\$millions) & 13.7 & 14.3 & 65.0 & 19.6 \\
Number of Employees & 97.9 & 65.5 & 50.2 & 119.6 \\
Total Hours Worked By Production & 159.5 & 79.3 & 75.0 & 202.5 \\
Workers (thousands) & & & & \\
Single Unit & $53 \%$ & $59 \%$ & $36 \%$ & $63 \%$ \\
Labor Productivity & 160.6 & 388.8 & $1,101.6$ & 164.1 \\
Energy Productivity & 626.3 & 773.1 & $1,292.6$ & 370.8 \\
Electricity Price & 41.5 & 37.4 & 47.8 & 35.9 \\
Natural Gas Price & 3.59 & 3.59 & 3.59 & 3.59 \\
Generated Electricity (millions) & 7.66 & 2.01 & 4.23 & 1.20 \\
Purchased Electricity (millions) & 11.94 & 11.66 & 18.63 & 26.21 \\
Vertical Integration & $39 \%$ & $15 \%$ & $19 \%$ & $4 \%$ \\
Number of Establishments & 5,868 & 13,474 & 2,146 & 5,059 \\
Number of Companies & 3,808 & 9,626 & 1,166 & 4,076 \\
\hline
\end{tabular}

${ }^{1}$ All data are from publicly available CMF files for the selected manufacturing industries for the year 1997. The public data is downloadable via https://www.census.gov/prod/ec97/97m31s-gs.pdf (last accessed Feb. 2015). Data on natural gas prices is from the EIA's average US price of natural gas for industry in 1997. 
Table III. Estimates of plant-level changes in vertical integration in response to NOx regulation. ${ }^{a}$

\begin{tabular}{|c|c|c|}
\hline \multirow{2}{*}{$\frac{\text { Variable Name }}{\text { Electricity Price }}$} & \multicolumn{2}{|c|}{$\begin{array}{l}\text { Estimated Coefficients } \\
\text { (standard errors) }\end{array}$} \\
\hline & 0.0006 & 0.0006 \\
\hline & $(0.0004)$ & $(0.0004)$ \\
\hline \multirow[t]{2}{*}{ Natural Gas Price } & $8.62 \mathrm{e}-05$ & $5.34 \mathrm{e}-05$ \\
\hline & $(0.0007)$ & $(0.0007)$ \\
\hline \multirow[t]{2}{*}{ RECLAIM } & -0.014 & -0.014 \\
\hline & $(0.016)$ & $(0.016)$ \\
\hline \multirow[t]{2}{*}{ NOx RACT } & $-0.031 * * *$ & $-0.031 * * *$ \\
\hline & $(0.010)$ & $(0.010)$ \\
\hline Fixed Effects Included: & $\begin{array}{c}\text { Plant, Year, } \\
\text { Industry-by-year }\end{array}$ & $\begin{array}{c}\text { Plant, Year, } \\
\text { Industry-by-year }\end{array}$ \\
\hline Plant Characteristics Included: & No & Yes \\
\hline Number of obs. ${ }^{\text {b }}$ & 59,600 & 59,600 \\
\hline R-squared & 0.029 & 0.031 \\
\hline Number of Plants & 16,100 & 16,100 \\
\hline \multicolumn{3}{|c|}{ 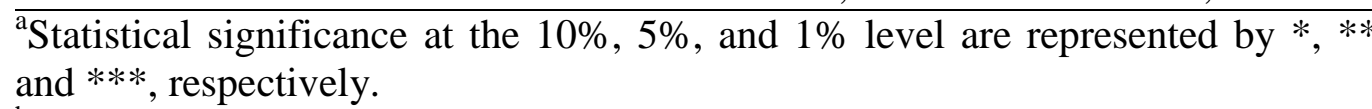 } \\
\hline
\end{tabular}


Table IV. Estimates of plant-level changes in extensive vertical integration, electricity use, and energy productivity. ${ }^{\mathrm{a}}$

\begin{tabular}{|c|c|c|c|c|}
\hline \multirow[b]{3}{*}{ Variable Name } & \multicolumn{4}{|c|}{ Dependent Variable: } \\
\hline & $\begin{array}{c}\text { Vertical } \\
\text { Integration } \\
\text { Indicator }\end{array}$ & $\begin{array}{l}\text { Ln(Purchased } \\
\text { Electricity) }\end{array}$ & $\begin{array}{c}\text { Ln(Total } \\
\text { Electricity) }\end{array}$ & $\begin{array}{c}\text { Ln(Energy } \\
\text { Productivity) }\end{array}$ \\
\hline & \multicolumn{4}{|c|}{$\begin{array}{c}\text { Estimated Coefficients } \\
\text { (Std. Error) }\end{array}$} \\
\hline Electricity Price & $\begin{array}{c}0.0005 \\
(0.0007)\end{array}$ & $\begin{array}{c}-0.237 * * * \\
(0.035)\end{array}$ & $\begin{array}{c}-0.235 * * * \\
(0.034)\end{array}$ & $\begin{array}{c}0.165 * * * \\
(0.043)\end{array}$ \\
\hline Natural Gas Price & $\begin{array}{c}0.001 \\
(0.001)\end{array}$ & $\begin{array}{l}-0.004 \\
(0.008)\end{array}$ & $\begin{array}{l}-0.005 \\
(0.008)\end{array}$ & $\begin{array}{c}0.094 * * * \\
(0.007)\end{array}$ \\
\hline RECLAIM & $\begin{array}{l}-0.051 * \\
(0.030)\end{array}$ & $\begin{array}{l}-0.044 \\
(0.082)\end{array}$ & $\begin{array}{l}-0.069 \\
(0.083)\end{array}$ & $\begin{array}{l}0.202 * * * \\
(0.075)\end{array}$ \\
\hline NOx RACT & $\begin{array}{c}-0.045 * * * \\
(0.015)\end{array}$ & $\begin{array}{c}0.022 \\
(0.034)\end{array}$ & $\begin{array}{l}-0.069 * \\
(0.038)\end{array}$ & $\begin{array}{l}-0.045^{*} \\
(0.025)\end{array}$ \\
\hline Fixed Effects Included: & $\begin{array}{l}\text { Plant, } \\
\text { Year, } \\
\text { Industry- } \\
\text { by-year }\end{array}$ & $\begin{array}{c}\text { Plant, Year, } \\
\text { Industry-by- } \\
\text { year }\end{array}$ & $\begin{array}{l}\text { Plant, } \\
\text { Year, } \\
\text { Industry- } \\
\text { by-year }\end{array}$ & $\begin{array}{c}\text { Plant, Year, } \\
\text { Industry-by- } \\
\text { year }\end{array}$ \\
\hline Plant Characteristics & & & & \\
\hline Included: & No & No & No & No \\
\hline Number of obs. ${ }^{b}$ & 59,600 & 59,600 & 59,600 & 59,600 \\
\hline R-squared & 0.033 & 0.058 & 0.056 & 0.053 \\
\hline Number of Plants & 16,100 & 16,100 & 16,100 & 16,100 \\
\hline
\end{tabular}


Figure 1: Vertical Integration Over Time for RECLAIM Participants. ${ }^{a}$

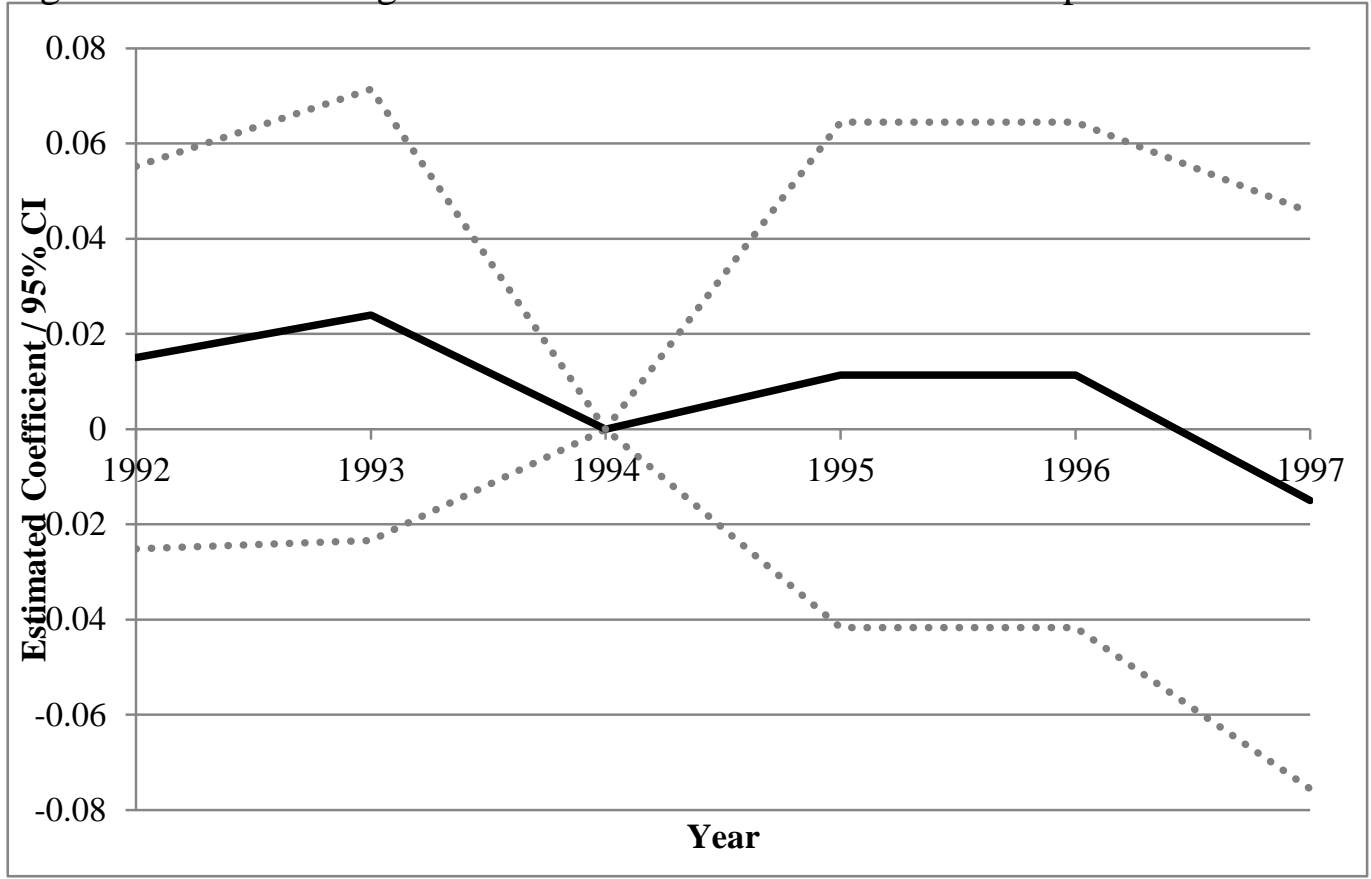

${ }^{a}$ Results based on estimation of equation (9). RECLAIM program years 1995 and 1996 are pooled into a single indicator variable to avoid disclosure risks from changing ASM samples, but each separate indicator for 1995 and 1996 was also individually statistically indistinguishable from zero. 
Figure 2: Vertical Integration Over Time for NOx RACT Participants

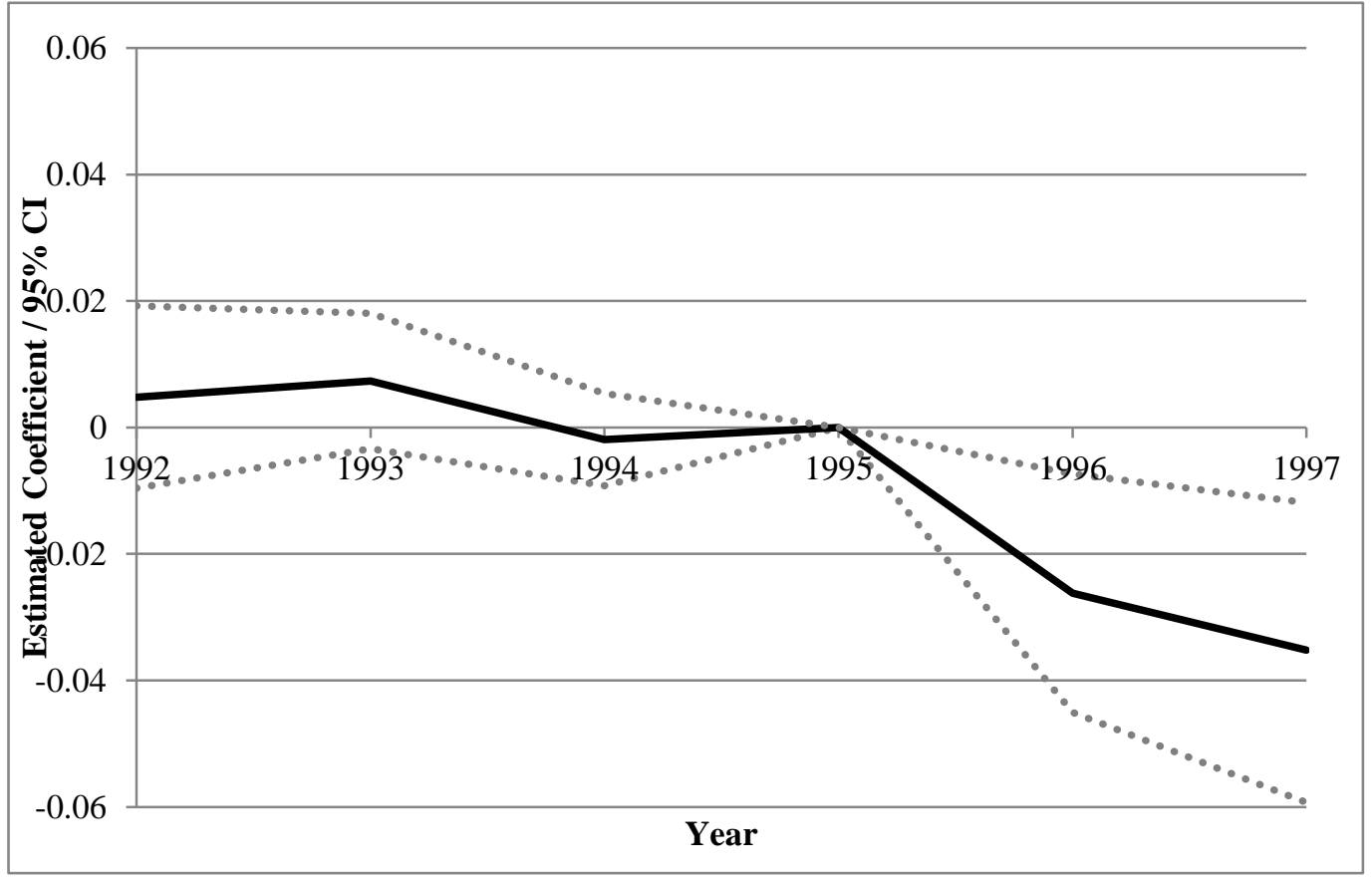

${ }^{\mathrm{a}}$ Results based on estimation of equation (9). 